\title{
Fishes of Alto Jacuí sub-basin: a poorly studied sub-basin of northwestern Rio Grande do Sul, Brazil
}

\author{
Karine O. Bonato* and Clarice B. Fialho \\ Universidade Federal do Rio Grande do Sul, Instituto de Biociências, Departamento de Zoologia, Programa de Pós-Graduação em \\ Biologia Animal, CEP 91501-970, Porto Alegre, RS, Brazil \\ * Corresponding author. E-mail: kakabio2005@yahoo.com.br
}

\begin{abstract}
The streams in the state of Rio Grande do Sul (mainly in the Alto Jacuí sub-basin belonging to the Laguna dos Patos system) have scarce information about their ichthyofauna. Thereby for providing information about stream species, the purpose of the present study was to inventory the ichthyofauna of the streams of the Alto Jacuí sub-basin, located in northwestern state of Rio Grande do Sul. The samples were taken bimonthly from June 2012 to June 2013 using electrofishing technique in 10 streams. A total of 13,247 specimens were collected belonging to 42 species, 10 families and six orders. We report the occurrence of five new species that have not yet been described by researchers.
\end{abstract}

Key words: stream; Alto Jacuí sub-basin; Laguna dos Patos system; ichthyofauna inventory

\section{INTRODUCTION}

Fish are considered the most diverse group of vertebrates (Lowe-MacConnell 1999), with an estimated richness of 32,900 species (Froese and Pauly 2014). By December 2013, Pelayo-Villamil et al. (2014) had found 14,782 described species of fish that occur only in freshwater. Although there is a lack of a complementary information, current estimates of the icthyofauna in the Neotropical region are that there are about 6,000 to 8,000 species, totaling $13 \%$ of the vertebrate biodiversity in aquatic ecosystems worldwide, with Brazilian continental waters showing $21 \%$ of global diversity (Reis et al. 2003; Agostinho et al. 2005).

There is still a lack of knowledge of fish richness, mainly in South America, Africa and Asia, whichis due to a lack of sampling and databasingPelayo-Villamil et al. 2014). Brazil has the largest river networks in the world (Galves et al. 2009); however, many Brazilian basins and sub-basins have not yet been sampled (Agostinho et al. 2005), or there exists little information about their fish fauna, especially with medium-sized and small water bodies such as streams (Castro 1999). According to Langeani et al. (2007) streams are the environments that have the highest number of new species still to be discovered. But the small size of streams and headwater environments makes these places more susceptible to anthropogenic action and they may experience significant change in their population structure, leading to the disappearance of the most sensitive species (Galves et al. 2009). This situation makes it difficult to understand ecological, biological and biogeographical processes (Barletta et al. 2010).

Although the situation has been changing in the last two decades with an increase of studies (biological, ecological and systematic studies) in streams, there is a lack of knowledge in some regions such as in southern Brazil. Most studies in the state of Rio Grande do Sul refer to large rivers, lagoons or estuarine areas (Fialho et al. 1998; Garcia and Vieira 2001; Bastos 2002; Garcia et al. 2003; Majolo 2005; Maltchik et al. 2005; Dufech and Fialho 2006; Garcia et al. 2006; Petry and Schulz 2006; Ribeiro and Köhler 2007; Dufech and Fialho 2009; Flores-Lopes et al. 2010; Saccol-Pereira and Fialho 2010). The only stream environment studies from Rio Grande do Sul are: Tagliani (1994), Becker (2002), Bozzeti and Schulz (2004), Vilella et al. (2004), Hirschmann (2009), Silva (2009), Winkler-Sosinski et al. (2009), Costa and Schulz (2010) and Volcan et al. (2011).

Little information are available about sampling and studies of the ichthyofauna in streams for the Jacuí river basin and no studies of the upper region of the basin, called the Alto Jacuí sub-basin. Malabarba (1989) showed a list of freshwater fish present in the Laguna dos Patos system and cited species found in Jacuí River and its tributaries. Alves and Fontoura (2009) identified the distributive pattern of migratory fish of the Jacuí River basin, but the data were obtained through interviews, collections, literature and technical studies (EIA-RIMA 
Estudo e Relatório de Impacto Ambiental) developed in the study region. Additionally there are some taxonomic reviews and descriptions of new species that are distributed on this drainage (Ottoni and Cheffe 2009; Menezes and Ribeiro 2010; Carvalho and Reis 2011).

We emphasize that to understand the ecological mechanisms in these little-explored environments we must use many tools, including ichthyofaunal studies. Streams are highly heterogeneous environments (Winemiller et al. 2008) and this allows for the establishment of numerous species of fish. Further, more studies of streams in south Brazil are necessary because some basins are not as well explored as the Alto Jacuí sub-basin. Therefore, the aim of this study is to inventory and provide more information about distribution and species richness of ichthyofauna in the Alto Jacuí sub-basin located in northwestern Rio Grande do Sul.

\section{MATERIALS AND METHODS Study site}

The Alto Jacuí sub-basin belongs to the large Laguna dos Patos system and is located in the state of Rio Grande do Sul in the northwestern Middle Plateau and Central Depression region. The Alto Jacuí has its headwaters located in the municipality of Passo Fundo and occupies an area of $16,062 \mathrm{~km}^{2}$ with its rivers flowing into the Lago Guaíba (COAJU 2009). The basin's vegetation consists of Seasonal Deciduous Forest and some areas of
Subtropical Ombrophilous Forest. The economy is based on agriculture (soybeans, corn, wheat and rice) and livestock. The basin is drained by the Jacuí, Jacuí-Mirim, Jacuizinho, Caixões, Ivaí and Soturno rivers (SEMA 2010). The Jacuí River is the main tributary of the basin and it is responsible for $85 \%$ of the waters forming the Lago Guaíba (FEPAM 2011).

Thus, this study was conducted in 10 streams (Figures 1 and 2-11) in northwestern Rio Grande do Sul, which corresponds to the Alto Jacuí sub-basin (Table 1). All streams flow into the Jacuí River, which is one of the main tributaries to the Laguna dos Patos system.

\section{Data collection}

Fish samples were collected with authorization number 34940 from register number 3196382 from Instituto Chico Mendes de Conservação da Biodiversidade (ICMBio). This study was approved by the Ethics Committee on Animal Use of the Universidade Federal do Rio Grande do Sul (permit number 24434) and was conducted in accordance with protocols in their ethical and methodological aspects for the use of fish.

The fish were collected in June, August, October and December 2012; February, April and June 2013. Each sampling event lasted four days. For the sampling, we used electrofishing with three stages of $30 \mathrm{~min}$ each, in stretches of $50 \mathrm{~m}$ per sampling stream. After sampling, fish were euthanized with $10 \%$ eugenol (Vidal et al. 2008; Lucena et al. 2013a), fixed in 10\% formalin

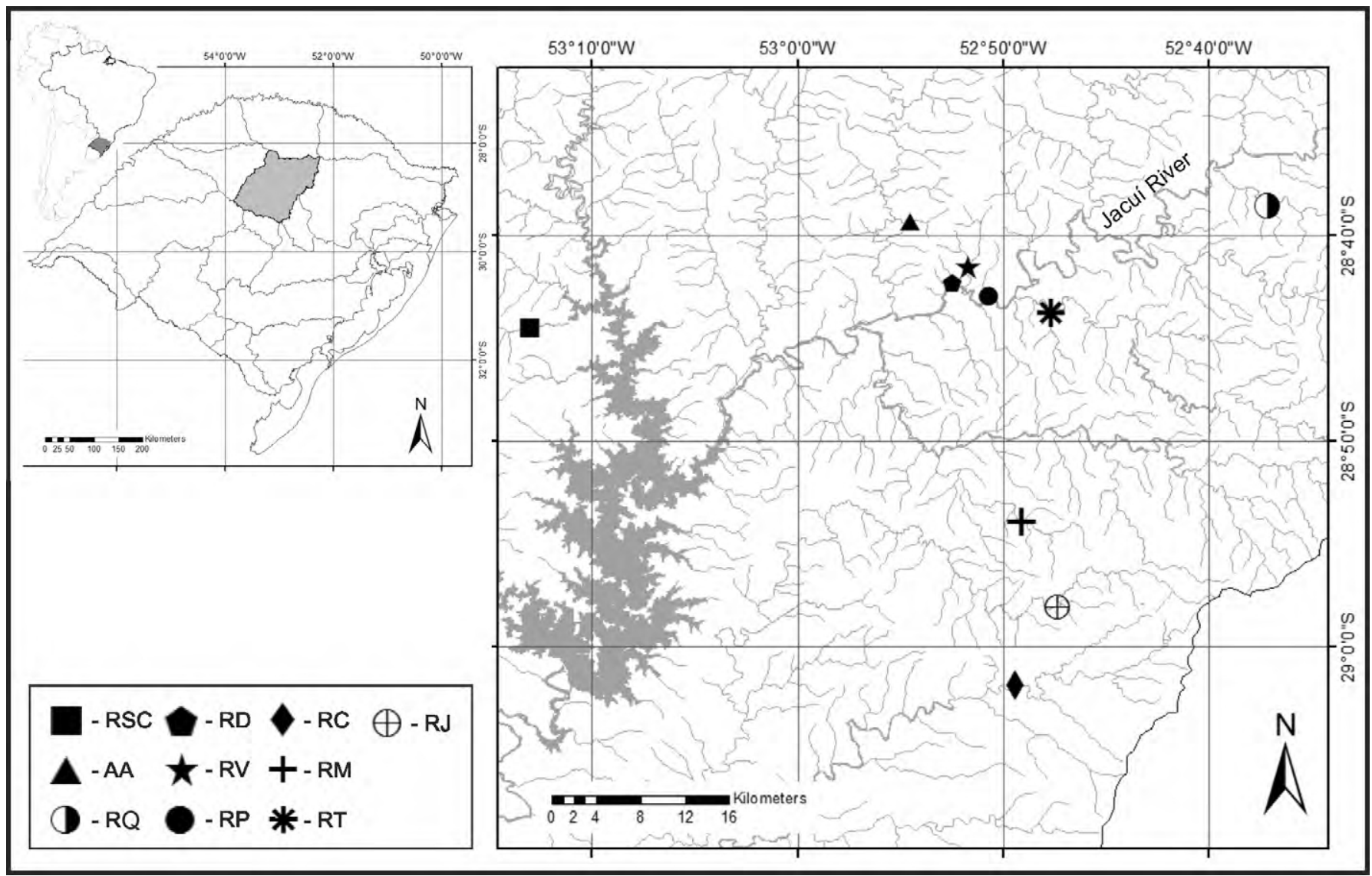

Figure 1. Sampling streams in the Alto Jacuí sub-basin. For stream code see Table 1. 
and then transferred to $70 \%$ alcohol for conservation. The taxonomic identification was carried out in the laboratory using Rodriguez and Reis (2008), Bertaco and
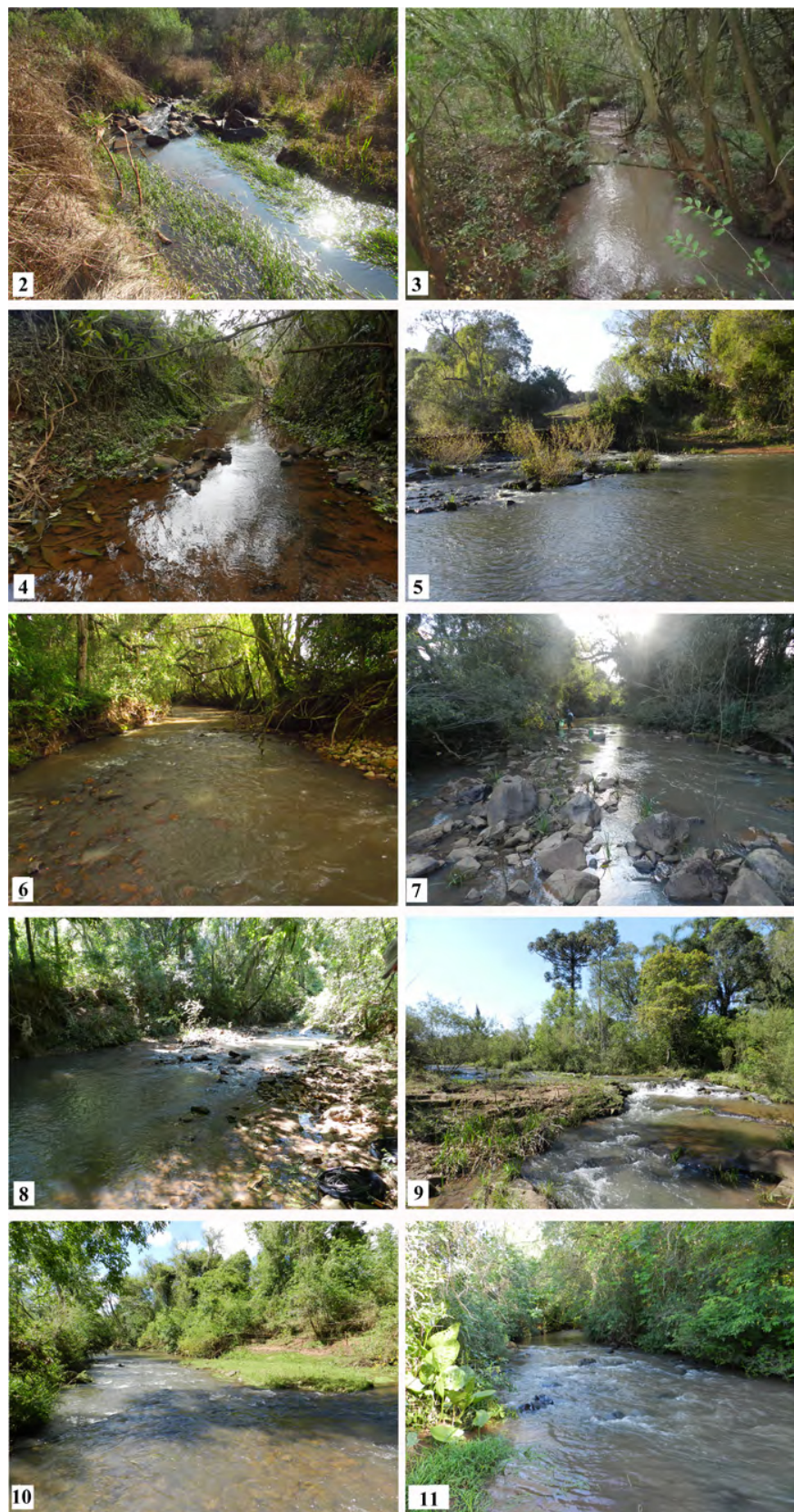

Figures 2-11. General view of the sampled streams in the Alto Jacuí subbasin, Rio Grande do Sul, Brazil: 2: AA; 3: RP; 4: RD; 5 : RC; 6: RJ; 7: RM; 8: RQ; 9: RSC; 10: RT; 11: RV. For stream code see Table 1.
Lucena (2010), Ferrer and Malabarba (2013), Lucena et al. (2013b), Lucena and Soares (2016) and additional literature cited herein. Classification and nomenclature follows Reis et al. (2003), with additional changes made by Thomaz et al. (2015) for Characidae. The nomenclature for Cichlidae followed the new classification of bony fishes proposed by Betancur et al. (2013) that include this family in the order Cichliformes. The voucher specimens were deposited in the fish collection of the Departamento de Zoologia at Universidade Federal do Rio Grande do Sul (UFRGS; Table 2).

\section{RESULTS}

A total of 13,247 specimens belonging to 42 species, ten families and six orders (Table 2 and Figures 12-32) were collected. The most significant orders were Characiformes (36\%), Cichliformes (24\%) and Siluriformes (14\%), with 15, 10 and six species, respectively. Cyprinodontiformes was represented by two species, and both Gymnotiformes and Synbranchiformes were represented by only one species. The predominant families were Characidae (12 species, 29\%), Loricariidae (nine species, 21\%), Cichlidae (seven species, 17\%) and Heptapteridae (four species, 10\%), followed by Crenuchidae, Poeciliidae and Trychomycteridae with two species (5\% each). Erythrinidae, Pimelodidae, Gymnotidae and Synbranchidae showed one species, corresponding to $2 \%$ each of the total richness.

Five species are identified only to genus level and correspond to undescribed species: Australoheros sp. (Rícan and Kullander 2008), Bryconamericus sp. b (Silva 1998), Heptapterus sp. (Bockmann 1998), Ituglanis sp. (J. Ferrer, personal communication) and Bryconamericus sp. a which also seem to be a new species but, could not be described because it may just be a variation (as color and body shape) of Bryconamericus iheringii. According to Bonato and Ferrer (2013), the individuals of Phalloceros spiloura Lucinda, 2008 collected in the Alto Jacuí subbasin during the present study represent the first record of this species to the Laguna dos Patos system.

The highest species richness was found in RP, RT, RC and RQ with 28 species, 27 species, 25 species and 21 species, respectively. RM and RSC showed the lowest species richness with only 15 and 14 sample species.

Table 1. Geographic coordinates, elevation and localization of the sampled streams and their respective codes in the Alto Jacuí sub-basin.

\begin{tabular}{lllll}
\hline Stream & Code & Geographic coordinates & Elevation (m) & Locality \\
\hline Caixões River & RC & $29^{\circ} 01^{\prime} 54.4^{\prime \prime} \mathrm{S}, 052^{\circ} 49^{\prime} 25.1^{\prime \prime} \mathrm{W}$ & 420 & Guanxuma, Espumoso \\
Jacuizinho River & RJ & $28^{\circ} 58^{\prime} 02.9^{\prime \prime} \mathrm{S}, 052^{\circ} 47^{\prime} 20.3^{\prime \prime} \mathrm{W}$ & 513 & Depósito, Espumoso \\
Morcego River & RM & $28^{\circ} 53^{\prime} 55.0^{\prime \prime} \mathrm{S}, 052^{\circ} 49^{\prime} 05.6^{\prime \prime} \mathrm{W}$ & 461 & São Domingos, Espumoso \\
Turvo River & RT & $28^{\circ} 43^{\prime} 47.0^{\prime \prime} \mathrm{S}, 052^{\circ} 47^{\prime} 40.4^{\prime \prime} \mathrm{W}$ & 351 & Santo Antônio, Espumoso \\
Quati River & RQ & $28^{\circ} 38^{\prime} 31.8^{\prime \prime} \mathrm{S}, 052^{\circ} 37^{\prime} 07.9^{\prime \prime} \mathrm{W}$ & 439 & Mormaço \\
Santa Clara River & RSC & $28^{\circ} 44^{\prime} 30.1^{\prime \prime} \mathrm{S}, 053^{\circ} 13^{\prime} 03.0^{\prime \prime} \mathrm{W}$ & 439 & Santa Clara, XV de Novembro \\
Valoroso Stream & RV & $28^{\circ} 41^{\prime} 32.0^{\prime \prime} \mathrm{S}, 052^{\circ} 51^{\prime} 41.5^{\prime \prime} \mathrm{W}$ & 376 & Teutônia, Tapera \\
Divinéia Stream & RD & $28^{\circ} 42^{\prime} 16.7^{\prime \prime} \mathrm{S}, 052^{\circ} 52^{\prime} 25.9^{\prime \prime} \mathrm{W}$ & 350 & Teutônia, Tapera \\
Paz Stream & RP & $28^{\circ} 42^{\prime} 57.3^{\prime \prime} \mathrm{S}, 052^{\circ} 50^{\prime} 41.7^{\prime \prime} \mathrm{W}$ & 378 & Vila Paz, Tapera \\
Angico Stream & AA & $28^{\circ} 39^{\prime} 17.9^{\prime \prime} \mathrm{S}, 052^{\circ} 54^{\prime} 31.1^{\prime \prime} \mathrm{W}$ & 368 & São Rafael, Tapera \\
\hline
\end{tabular}


Table 2. List of fish species collected at each sampled stream in the Alto Jacuí sub-basin. See Table 1 for stream names. Asterisk indicates the endemic species to Laguna dos Patos system.

\begin{tabular}{|c|c|c|c|c|c|c|c|c|c|c|c|}
\hline \multirow[b]{2}{*}{ Taxa } & \multicolumn{10}{|c|}{ Streams } & \multirow[b]{2}{*}{ Voucher (UFRGS } \\
\hline & RC & RJ & RM & $\mathbf{R V}$ & RD & AA & RSC & $\mathbf{R Q}$ & $\mathbf{R P}$ & RT & \\
\hline \multicolumn{12}{|l|}{ CHARACIFORMES } \\
\hline \multicolumn{12}{|l|}{ Characidae } \\
\hline Astyanax lacustris (Lütken, 1875) & $x$ & & & $\mathrm{x}$ & $x$ & $x$ & & $x$ & $x$ & $x$ & 19977 \\
\hline Astyanax laticeps (Cope, 1894) & & & & & $\mathrm{x}$ & & $\mathrm{x}$ & & & $\mathrm{x}$ & 19327 \\
\hline Astyanax obscurus (Hensel, 1870) * & $x$ & & & & & & $x$ & & $x$ & & 19329 \\
\hline Astyanax procerus Lucena, Castro \& Bertaco, 2013* & $\mathrm{x}$ & $x$ & $\mathrm{x}$ & $\mathrm{x}$ & $\mathrm{x}$ & $\mathrm{x}$ & $\mathrm{x}$ & $\mathrm{x}$ & $\mathrm{x}$ & $\mathrm{x}$ & 19323 \\
\hline Astyanax xiru Lucena, Castro \& Bertaco, 2013 & $\mathrm{x}$ & & $\mathrm{x}$ & & $\mathrm{x}$ & $\mathrm{x}$ & & & $\mathrm{x}$ & $\mathrm{x}$ & 19325 \\
\hline Bryconamericus iheringii (Boulenger, 1887) & $\mathrm{x}$ & $x$ & $\mathrm{x}$ & $x$ & $\mathrm{x}$ & $\mathrm{x}$ & $\mathrm{x}$ & $\mathrm{x}$ & $\mathrm{x}$ & $\mathrm{x}$ & 19974 \\
\hline Bryconamericus sp. a & $x$ & $\mathrm{x}$ & & & & & & & & & 19975 \\
\hline Bryconamericus sp. $b$ * & $x$ & & & & & & & & & & 19980 \\
\hline Diapoma alburnus (Hensel, 1870) & $\mathrm{x}$ & $\mathrm{x}$ & $\mathrm{x}$ & & & & & $\mathrm{x}$ & $\mathrm{x}$ & $\mathrm{x}$ & 19976 \\
\hline Diapoma dicropotamicus (Malabarba \& Weitzman, 2003) * & & & $\mathrm{x}$ & & & & & $\mathrm{x}$ & & & 19952 \\
\hline Oligosarcus jacuiensis Menezes \& Ribeiro, 2010 & $x$ & $\mathrm{x}$ & & & $\mathrm{x}$ & $x$ & $\mathrm{x}$ & $\mathrm{x}$ & $\mathrm{x}$ & $x$ & 19978 \\
\hline Oligosarcus jenynsii (Günther, 1864) & & & & $\mathrm{x}$ & & $\mathrm{x}$ & & $\mathrm{x}$ & $\mathrm{x}$ & $\mathrm{x}$ & 19979 \\
\hline \multicolumn{12}{|l|}{ Crenuchidae } \\
\hline Characidium orientale Buckup \& Reis, 1997 & $\mathrm{x}$ & & & & & & & & & & 19962 \\
\hline Characidium pterostictum Gomes, 1947 & $\mathrm{x}$ & $\mathrm{x}$ & $\mathrm{x}$ & $\mathrm{x}$ & $\mathrm{x}$ & $\mathrm{x}$ & $\mathrm{x}$ & $\mathrm{x}$ & $\mathrm{x}$ & $\mathrm{x}$ & 19973 \\
\hline \multicolumn{12}{|l|}{ Erythrinidae } \\
\hline Hoplias malabaricus (Bloch, 1794) & & $\mathrm{x}$ & $\mathrm{x}$ & & & $\mathrm{x}$ & & & $\mathrm{x}$ & $\mathrm{x}$ & 19961 \\
\hline
\end{tabular}

\section{SILURIFORMES}

\section{Heptapteridae}

Rhamdia quelen (Quoy \& Gaimard, 1824)

Rhamdella eriarcha (Eigenmann \& Eigenmann, 1888)

Heptapterus mustelinus (Valenciennes, 1835)

Heptapterus sp.

\section{Trichomycteridae}

Ituglanis sp.

Trichomycterus poikilos Ferrer \& Malabarba, 2013 *

\section{Loricariidae}

Ancistrus brevipinnis (Regan, 1904)

Eurycheilichthys limulus Reis \& Schaefer, 1998

Hemiancistrus punctulatus Cardoso \& Malabarba, 1999*

Hisonotus armatus Carvalho, Lehmann, Pereira \& Reis, 2008 *

Hisonotus brunneus Carvalho \& Reis, 2011 *

Hypostomus commersoni (Valenciennes, 1836)

Rineloricaria baliola Rodriguez \& Reis, 2008

Rineloricaria cadeae (Hensel, 1868) *

Rineloricaria microlepidogaster (Regan, 1904)

Pimelodidae

Pimelodus pintado Azpelicueta, Lundberg \& Loureiro, 2008

\section{GYMNOTIFORMES}

\section{Gymnotidae}

Gymnotus aff. carapo Linnaeus, 1758

\section{CICHLIFORMES}

\section{Cichlidae}

Australoheros sp.

Crenicichla lepidota Heckel, 1840

Crenicichla punctata Hensel, 1870

Geophagus brasiliensis (Quoy \& Gaimard, 1824)

Gymnogeophagus gymnogenys (Hensel, 1870)

$\begin{array}{lllllllll}X & X & X & X & X & X & X & X & X\end{array}$

$\begin{array}{lll}X & 19951\end{array}$

$\begin{array}{llll}X & X & 19967\end{array}$

$\begin{array}{lllllllllll}X & X & X & X & X & X & X & X & X & X & 19266\end{array}$

Gymnogeophagus labiatus (Hensel, 1870)

Gymnogeophagus rhabdotus (Hensel, 1870)

\begin{tabular}{|c|c|c|c|c|c|c|c|c|c|c|}
\hline & & & & & & & & $x$ & & 19949 \\
\hline$x$ & $x$ & $x$ & $x$ & $x$ & $x$ & $x$ & $x$ & $x$ & $x$ & 19267 \\
\hline$x$ & $x$ & $x$ & $x$ & $x$ & $x$ & $x$ & $x$ & $x$ & $x$ & 19984 \\
\hline$x$ & $x$ & $x$ & $x$ & $x$ & $x$ & $x$ & $x$ & $x$ & $x$ & 19985 \\
\hline$x$ & $x$ & & $x$ & $x$ & $x$ & & $x$ & $x$ & $x$ & 19986 \\
\hline$x$ & & & & & & & & & & 19957 \\
\hline & $x$ & & & & & & $x$ & & & 19959 \\
\hline & & & & $x$ & & & & $x$ & & 19958 \\
\hline & $x$ & $x$ & $x$ & $x$ & $x$ & $x$ & $x$ & $x$ & $x$ & 19982 \\
\hline & & & $x$ & & $x$ & & $x$ & $x$ & $x$ & 19983 \\
\hline
\end{tabular}

\section{CYPRINODONTIFORMES}

Poeciliidae

Phalloceros caudimaculatus (Hensel, 1868)

Phalloceros spiloura Lucinda, 2008

X $\quad X \quad 19960$

\section{SYNBRANCHIFORMES}

Synbranchidae

Synbranchus marmoratus Bloch, 1795 $\mathrm{X}$

X $\quad$ X $\quad$ X 19966

$\begin{array}{llllllllll}25 & 18 & 15 & 18 & 17 & 18 & 14 & 21 & 28 & 27\end{array}$



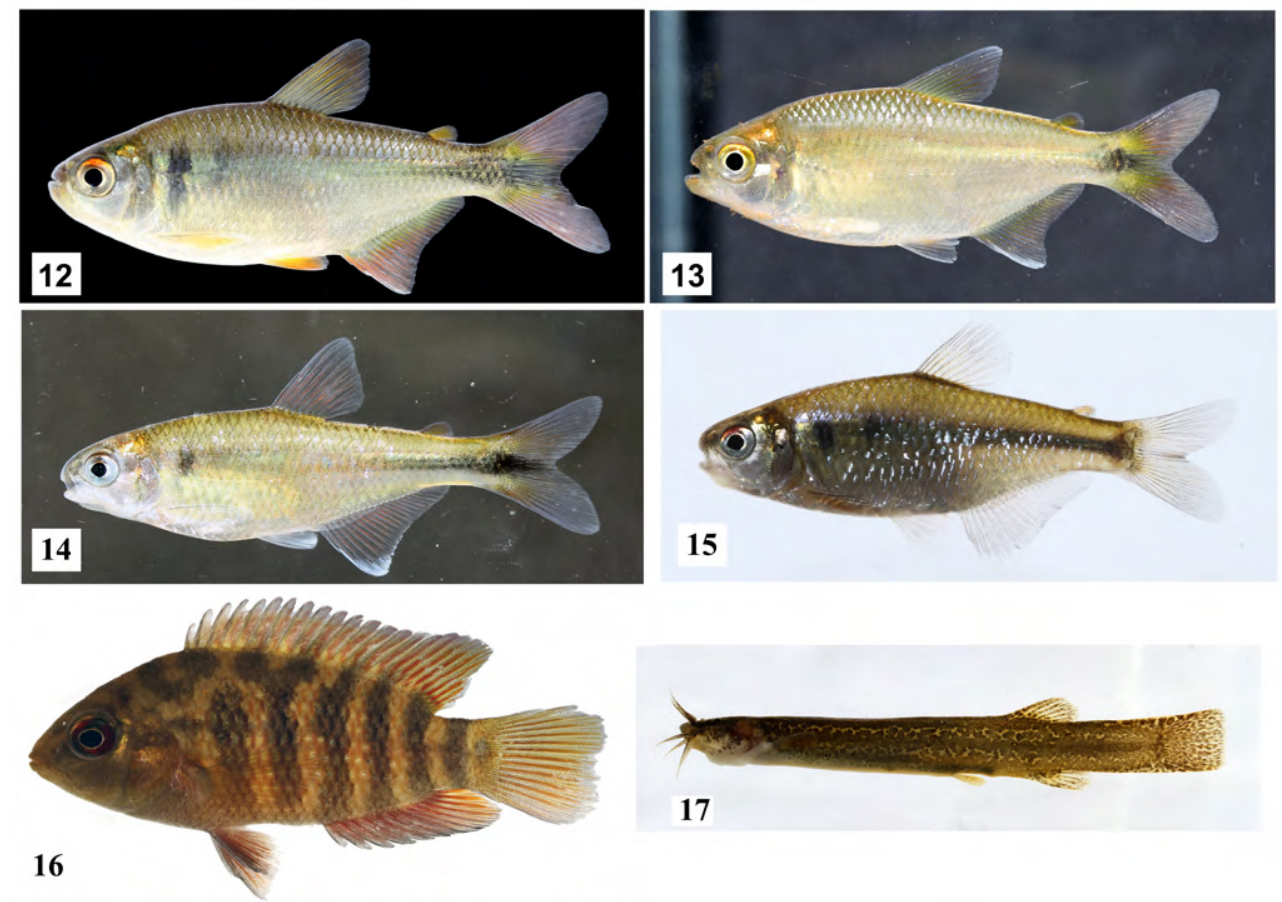

17
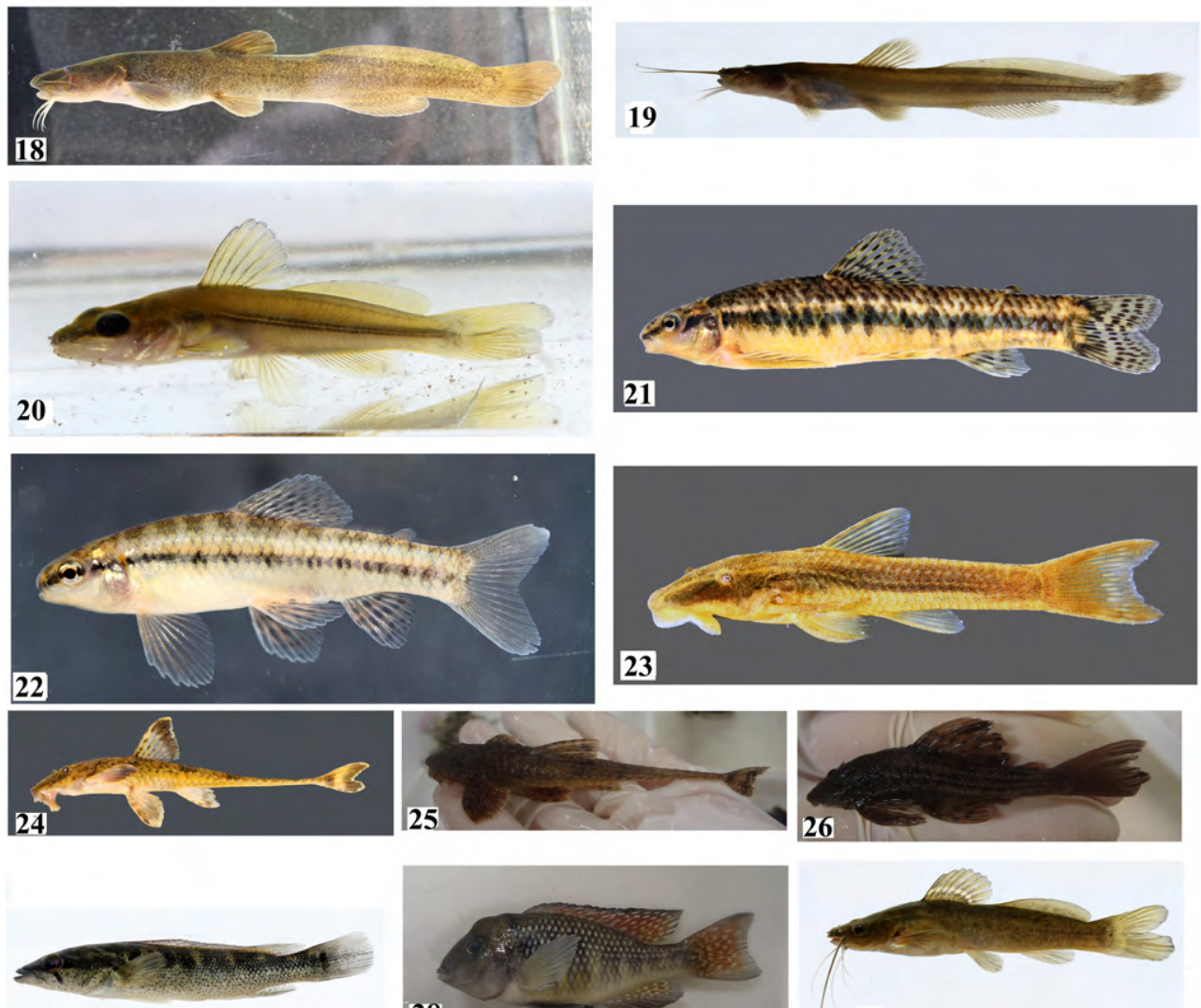

27
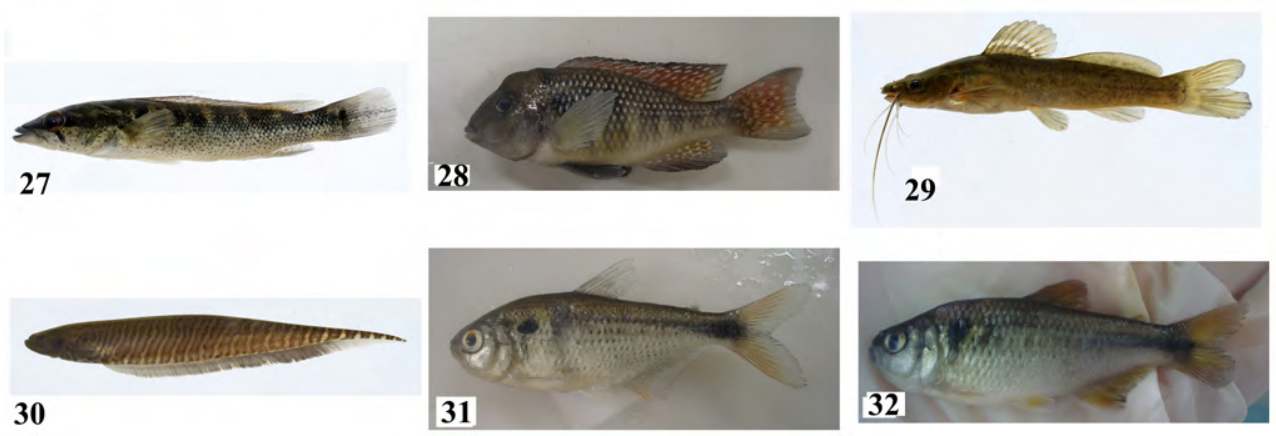

Figures 12-32. Some species of fishes found in Alto Jacuí sub-basin, Rio Grande do Sul. Photos by L.R. Malabarba. 12: Astyanax xiru, 13: Astyanax procerus, 14: Bryconamericus sp. b (UFRGS 17931), 15: Bryconamericus iheringii (UFRGS 17992), 16: Australoheros sp.(UFRGS 17989), 17: Trichomycterus poikilos, 18: Heptapterus sp. (UFRGS 17933), 19: Heptapterus mustelinus,20: Rhamdella eriarcha (UFRGS 17984), 21: Characidium pterostictum (UFRGS 17826), 22: Characidium orientale, 23: Eurycheilichthys limulus (UFRGS 17986), 24: Rineloricaria baliola (UFRGS 17991), 25: Rineloricaria cadeae, 26: Hypostomus commersoni, 27: Creniciclha punctata (UFRGS 17990), 28: Gymnogeophagus gymnogenys, 29: Rhamdia quelen, 30: Gymnotus aff. carapo (UFRGS 17989), 31: Astyanax laticeps, 32: Astyanax obscurus. 


\section{DISCUSSION}

According to Pelayo-Villamil et al. (2014) an average of 240.2 species of fishes were described per year in the last ten years worldwide. The five new species uncovered by this inventory (Australoheros sp., Heptapterus sp., Bryconamericus sp. a and b, and Ituglanis sp.) support the importance of this type of study. In addition, inventories are important in extending the distributional range of some species, such as Phalloceros spiloura that was previously only known from the coastal drainages of states of Rio Grande do Sul and Santa Catarina, Iguaçu and Uruguay river basins, and as part of this study, was found in the Alto Jacuí sub-basin representing a new record for the Laguna dos Patos system (Bonato and Ferrer 2013).

Malabarba (1989) registred 25 species of the 42 species sampled in this study to Laguna dos Patos system. The most recent literature indicates a total of 160 species to the Laguna dos Patos system (Malabarba et al. 2009) including 35 species that were new species and yet not described in 2009. Of these 35 species listed by Malabarba et al. (2009), we have sampled five species that were described in recent years (Oligosarcus jacuiensis Menezes \& Ribeiro, 2010; Hisonotus brunneus Carvalho \& Reis, 2011; Astyanax procerus Lucena, Castro \& Bertaco, 2013; Astyanax xiru Lucena, Castro \& Bertaco, 2013; Trychomycterus poikilos Ferrer \& Malabarba, 2013), indicating that a representative amount of the ichthyofauna of the upper Jacuí River was described in recent years. There are no comparable studies for the Alto Jacuí sub-basin. We can only make comparisons with other basins belonging to the Laguna dos Patos system. For stream environments Bozzeti and Schulz (2004) found 57 species in the Gravataí and Sinos subbasins, Hirschmann (2009) found 55 species in the Forqueta sub-basin (Taquari-Antas basin), and Becker et al. (2013) found 119 species for the Taquari-Antas basin but in respect to the last study, the high number of captured species is likely due to their larger sampling of 519 sites.

The number of species found in this study is lower compared to those cited by other studies mainly because it was conducted in streams from a headwater region and many of the streams (of lower species richness) are first-order. The highest occurrence of the orders Characiformes, Cichliformes and Siluriformes in studies is also well documented for the Laguna dos Patos system and for the Neotropical region (Castro 1999; Garcia et al. 2003; Buckup et al. 2007; Lévêque et al. 2008; Costa and Schulz 2010). Headwater streams do not have an exclusive fish fauna but, species that form populations residing in streams and also that occur in larger bodies of water with different characteristics (Castro 1999). The fish fauna of streams is based on small species and according to Castro (1999) it seems to be the only general pattern with real diagnostic value for stream environments. In this study, the streams with lower species richness are the first-order streams, which have a habitat of lower complexity as RD, RV and AA streams (see Table 1 for stream codes). This situation is expected in accordance with the River Continuum Theory (Vannote et al. 1980). Thus, the larger streams, with greater width between banks, areas with and without shading, and more heterogeneous environment showed the highest species richness (Fereira and Casatti 2006; Súarez and Petrere-Junior 2005) as occurred in the RT, $\mathrm{RP}$ and RC streams.

Despite the fact that we did not evaluate the degree of anthropic influences in the sampled streams, all streams sampled here showed some kind of human interference. Most streams are very close to agricultural areas with the presence of dairy cattle or pig livestock. In stream $\mathrm{RP}$ there was a considerable amount of waste coming from homes and sometimes we found dead animals within the stream. Probably the residents of the region slaughter animals for their own consumption and discard the remains of the animal in the river. However, this stream had considerable marginal vegetation and a heterogeneous environment with changing pools and areas of rapids, which led to the high amount of richness observed.

Due to a lack of data for streams of the studied subbasin it is difficult to say that the number of species found is representative of the streams belonging to Laguna dos Patos system. The checklist showed 42 species representing $26 \%$ of the species mentioned for the Laguna dos Patos system. This study is an important record for the region of the Alto Jacuí sub-basin due to the lack of extensive collecting effort in the region. The expansion of the sampled streams in Jacuí River basin may increase the records of species and information about endemic species.

\section{ACKNOWLEDGEMENTS}

We thank the colleagues of the Ichthyology Lab at the Universidade Federal do Rio Grande do Sul for field work; MSc. J. Ferrer, MSc. P.C. Silva for help in identifying the species studied and Dr. L.R. Malabarba to provide the species figures; the Orlandi and Bonato families for help and support in field work; and Coordenação de Aperfeiçoamento de Pessoal de Nível Superior (CAPES, Proc. 1104786, to KOB) for financial support. We also thank to Adam J. Taylor for reviewing the English of this manuscript.

\section{LITERATURE CITED}

Agostinho, A.A., S.M. Thomaz and L.C. Gomes. 2005. Conservação da biodiversidade em águas continentais do Brasil. Megadiversidade 1(1): 70-78.

Alves, T.P. and N.F. Fontoura. 2009. Statistical distribution models for migratory fish in Jacuí basin, South Brazil. Neotropical Ichthyol- 
ogy 7(4): 647-658. doi: 10.1590/S1679-62252009000400014

Azpelicueta, M. delas M., J.G. Lundberg and M. Loureiro. 2008. Pimelodus pintado (Siluriformes: Pimelodidae), a new species of catfish from affluent rivers of Laguna Merín, Uruguay, South America. Proceedings of the Academy of Natural Sciences of Philadelphia 157:149-162. doi:10.1635/0097-3157(2008)157[149:PPSPAN]2. $0 . \mathrm{CO} ; 2$

Barletta, M., A.J. Jaureguizar, C. Baiguns, N.F. Fontoura, A.A. Agostinho, V.M.F. Almeida-Val, A.L. Val, R.A. Torres, L.F. Jímenes-Segura, T. Giarrizzo, N.N. Fabré, V.S. Batista, C. Lasso, D.C. Taphorin, M.F. Costa, P.T. Chaves, J.P. Vieira and M.F.M. Corrêa. 2010. Fish and aquatic habitat conservation in South America: a continental overview with emphasis on neotropical systems. Journal of Fish Biology 76: 2118-2176. doi: 10.1007/ s10641-014-0226-y

Bastos, J.R.H. 2002. Biologia alimentar da taxocenose de peixes do rio Silveira (cabeceira do rio Pelotas), São José dos Ausentes, Rio Grande do Sul, Brasil [M.Sc. dissertation]. Porto Alegre: Universidade Federal do Rio Grande do Sul. 67 pp.

Becker, F.G. 2002. Distribuição e abundância de peixes de corredeiras e suas relações com características de hábitat local, bacia de drenagem e posição espacial em riachos de mata Atlântica (bacia do rio Maquine, RS, Brasil) [Ph.D. thesis]. São Paulo: Universidade Federal de São Carlos. 190 pp.

Becker, F.G., L.C.C. De Fries, J. Ferrer, V.A. Bertaco, K.D.G. LuzAgostinho, J.F.P. Silva, A.R. Cardoso, Z.M.S. Lucena and C.A.S. Lucena. 2013. Fishes of the Taquari-Antas river basin (Patos Lagoon basin), Southern Brazil. Brazilian Journal of Biology 73(1): 79-90. doi: 10.1590/S1519-69842013000100010

Bertaco, A. and C.A.S. Lucena. 2010. Redescription of Astyanax obscurus (Hensel, 1870) and A. laticeps (Cope, 1894) (Teleostei: Characidae): two valid freshwater species originally described from rivers of Southern Brazil. Neotropical Ichthyology 8(1): 7-20. doi: 10.1590/S1679-62252010000100002

Betancur, R.R., R.E. Broughton, E.O. Wiley, K. Carpenter, J.A. López, C. Li, N.I. Holcroft, D. Arcila, M. Sanciangco, J.C. Cureton, F. Zhang, T. Buser, M.A. Campbell, J.A. Balesteros, A. Roa-Varon, S. Willis, W.C. Borden, T. Roelwy, P.C. Reneau, D.J. Hough, G. Lu, T. Grande, G. Arratia and G. Ortí. 2013. The tree of life and a new classification of bony fishes. PLoS Currents. doi: 10.1371/ currents.tol.53ba26640df0ccaee75bb165c8c26288

Bloch, M.E. 1794. Naturgeschichte der ausländischen Fische. Berlin: Hesse. 8: 1-174. http://biodiversitylibrary.org/page/41367521

Bloch, M.E. 1795. Naturgeschichte der ausländischen Fische. Berlin: Hesse. 9: 1-192. http://biodiversitylibrary.org/page/41367701

Bockmann, F.A. 1998. Análise filogenética da família Heptapteridae (Teleostei, Ostariophysi, Siluriformes) e redefinição de seus gêneros [Ph.D. thesis]. São Paulo: Universidade de São Paulo. 599 pp.

Boulenger, G.A.1887. Descriptions of new South-American characinoid fishes. Annals and Magazine of Natural History (5th series) 19(111): 172-174. http://biodiversitylibrary.org/page/16334767

Bonato, K.O. and J. Ferrer. 2013. New record and distribution extension of Phalloceros spiloura Lucinda, 2008 (Cyprinodontiformes: Poeciliidae). Check List 9(6): 1545-1547. doi: 10.15560/9.6.1545

Bozzetti, M. and U.H. Schultz. 2004. An index of biotic integrity base on fish assemblages for subtropical streams in southern Brazil. Hydrobiologia 529: 133-144. doi: 10.1007/s10750-004-5738-6

Buckup, P.A. and R.E. Reis. 1997. Characidiin genus Characidium (Teleostei, Characiformes) in southern Brazil, with description of three new species. Copeia 1997(3): 531-548. doi: 10.2307/1447557

Buckup, P.A., N.A. Menezes and M.S. Ghazzi. 2007. Catálogo das Espécies de Peixes de Água Doce do Brasil. Rio de Janeiro: Museu Nacional, Universidade Federal do Rio de Janeiro, Série Livros 23. $195 \mathrm{pp}$.
Carvalho, T.P., P. Lehmann, A.E.H.L. Pereira and R.E. Reis. 2008. A new species of Hisonotus (Siluriformes: Loricariidae: Hypoptopomatinae) from the Laguna dos Patos basin, southern Brazil. Copeia 2008(3): 510-516. doi: 10.1643/CI-07-130

Carvalho, T.P. and R.E. Reis. 2011. Taxonomic review of Hisonotus Eigenmann \& Eigenmann (Siluriformes: Loricariidae: Hypoptopomatinae) from the laguna dos Patos system, southern Brazil. Neotropical Ichthyology 9(1): 1-48. doi: 10.1590/S167962252011000100001

Castro, R.M.C. 1999. Evolução da ictiofauna de riachos sulamericanos: padrões gerais e possíveis processos causais; pp. 139-155, in E.P. Caramaschi, R. Mazzoni and R.P. Peres-Neto (eds.). Ecologia de Peixes de Riachos: Estado Atual e Perspectivas. Rio de Janeiro: Série Oecologia Brasiliensis.

COAJU (Comitê de gerenciamento de Bacias Hidrográficas do Alto Jacuí). [2009]. Plano de Gerenciamento da Bacia hidrográfica do Alto Jacuí. Relatório-T2. Consolidação das informações existentes sobre os recursos hídricos da bacia. Accessed at http:// www.upf.br/coaju/index.php?option=com_content\&task=view \&id=288\&Itemid=55, 20 June 2012

Cope, E.D. 1894. On the fishes obtained by the Naturalist Expedition in Rio Grande do Sul. Proceedings of the American Philosophical Society 33: 84-108. http://biodiversitylibrary.org/ page/29851042

Costa, P.F. and U.H. Schulz. 2010. The fish community as an indicator of biotic integrity of the streams in the Sinos River basin, Brazil. Brazilian Journal of Biology 70(4): 1195-1205. doi: 10.1590/ S1519-69842010000600009

Dufech, A.P.S and C.B. Fialho. 2006. Biologia populacional de Pachyurus bonariensis Steindachner, 1879 (Perciformes, Sciaenidae), uma espécie alóctone no sistema hidrográfico da laguna dos Patos, Brasil. Biota Neotropica 7(1): 105-110. http://www. biotaneotropica.org.br/v7n1/pt/abstract?article+bn032070120 07\%20ISSN\%201676-0603

Dufech, A.P.S and C.B. Fialho. 2009. Estudo comparado da taxocenose de peixes em dois ambientes aquáticos do Parque Estadual de Itapuã, sul do Brasil. Iheringia, Série Zoologia 99(2): 177-188. doi: 10.1590/S0073-47212009000200010

Eigenmann, C.H. and R.S. Eigenmann. 1888. Preliminary notes on South American Nematognathi. Proceedings of the California Academy of Sciences 1(2): 119-172. http://biodiversitylibrary. org/page/7133491

Ferreira, C.P. and L. Casatti. 2006. Influência da estrutura do hábitat sobre a ictiofauna de um riacho em uma micro-bacia de pastagem, São Paulo, Brasil. Revista Brasileira de Zoologia 23(3): 642-651. doi: 10.1590/S0101-81752006000300006

Ferrer, J. and L.R. Malabarba. 2013. Taxonomic review of genus Trichomycterus Valenciennes (Siluriformes: Trichomycteridae) from the laguna dos Patos system, Southern Brazil. Neotropical Ichthyology 11(2): 217-246. doi: 10.1590/S1679-62252013000200001

Fialho, C.B., L.C. Schifino and J.R. Verani. 1998. Biologia reprodutiva de Oligosarcus jenynsii (Günther) (Characiformes, Characidae) da Lagoa das Custódias, Tramandaí, Rio Grande do Sul, Brasil. Revista Brasileira de Zoologia 15(3): 775-782.

Flores-Lopes, F., M. Cetra and L.R. Malabarba. 2010. Utilização de índicesecológicos emassembléias depeixes comoinstrumentodeavaliação da degradação ambiental em programas de monitoramento. Biota Neotropica 10(4): 183-193. http://www.biotaneotropica. org.br/v10n4/pt/abstract?article+bn03710042010

Froese, R. and D. Pauly. [2014]. FishBase. Accessed at http://www. fishbase.org, 20 October 2014.

FEPAM (Fundação Estadual de Proteção Ambiental Herique Luiz Roessler - RS). [2012]. Base de Dados. Accessed at http://www. fepam.rs.gov.br/qualidade/guaiba.asp, 25 June 2012.

Galves, W., O.A. Shibatta, O.A. and F.C. Jerep. 2009. Estudos sobre a diversidade de peixes da bacia do alto rio Paraná: uma revisão 
histórica. Semina: Ciência Biológicas e da Saúde 30(2): 141-154.

Garcia, A.M. and J.P. Vieira, J.P. 2001. O aumento da diversidade de peixes no estuário da lagoa dos Patos durante o episódio El Niño 1997-1998. Atlântica 23: 85-96.

Garcia, A.M., M.B. Raseira, J.P. Vieira, K.O. Winemiller and A.M. Grimm. 2003. Spatiotemporal variation in shallow-water freshwater fish distribution and abundance in a large subtropical coastal lagoon. Environmental Biology of Fishes 68: 215-228. doi: 10.1023/A:1027366101945

Garcia, A.M., A.M. Bemvenuti, J.P. Vieira, D.M.L.M. Marques, M.D.M. Burns, A. Moresco and M.V.L. Condini. 2006. Checklist comparasion and dominance patterns of the fish fauna at Taim wetland, South Brazil. Neotropical Ichthyology 4(2): 261-268. doi: http://dx.doi.org/10.1590/S1679-62252006000200012

Gomes, A.L. 1947. A small collection of fishes from Rio Grande do Sul, Brazil. Miscellaneous Publications, Museum of Zoology, University of Michigan 67: 1-39. http://hdl.handle.net/2027.42/56312

Günther, A. 1864. Catalogue of the fishes in the British Museum. Catalogue of the Physostomi, containing the families Siluridae, Characinidae, Haplochitonidae, Sternoptychidae, Scopelidae, Stomiatidae in the collection of the British Museum 5: 1-455. http://biodiversitylibrary.org/page/8404768

Heckel, J. J. 1840. Johann Natterer's neue Flussfische Brasilien's nach den Beobachtungen und Mittheilungen des Entdeckers beschrieben (Erste Abtheilung, Die Labroiden). Annalen des Wiener Museums der Naturgeschichte 2: 325-471. http:// biodiversitylibrary.org/item/127839

Hensel, R. 1868. Beiträge zur Kenntniss der Wirbelthiere Südbrasiliens. Archiv für Naturgeschichte 34: 323-375.

Hensel, R. 1870. Beiträge zur Kenntniss der Wirbelthiere Südbrasiliens. Archiv für Naturgeschichte 36(1): 50-91. http:// biodiversitylibrary.org/page/7082229

Hirschmann, A. 2009. Composição e estrutura da assembleia de peixes em três arroios da sub-bacia do rio Forqueta, Sul do Brasil [M.Sc. dissertation]. Porto Alegre: Universidade Federal do Rio Grande do Sul. 70 pp.

Langeani, F., R.M.C. Castro, O.T. Oyakawa, O.A. Shibatta, C.S. Pavanelli and L. Casatti. 2007. Diversidade da ictiofauna do Alto Rio Paraná: composição atual e perspectivas futuras. Biota Neotropica 7(3): 181-197. http://www.biotaneotropica.org.br/v7n3/ pt/abstract?article+bn03407032007

Linnaeus, C. 1758. Systema Naturae, Ed. X. (Systema naturae per regna tria naturae, secundum classes, ordines, genera, species, cum characteribus, differentiis, synonymis, locis. Tomus I. Editio decima, reformata). Holmiae 1: 1-824. http://biodiversitylibrary. org/item/10277

Lêvèque, C., T. Oberdoff, D. Paugy, M. Stiassny and P.A. Tedesco. 2008. Global diversity of fish (Pisces) in freshwater. Hydrobiologia 595: 545-567. doi: 10.1007/s10750-007-9034-0

Lowe-McConnel, R.H.1999. Estudos Ecológicos de Comunidade de Peixes Tropicais. São Paulo: EDUSP. 536 pp.

Lucena, C.A.S., B.B. Calegari, E.H.L. Pereira and E. Dallegrave. 2013a. O uso de óleo de cravo na eutanásia de peixes. Boletim Sociedade Brasileira de Ictiologia 105: 20-24.

Lucena, C.A.S., J.B. Castro and V.A. Bertaco. 2013b. Three new species of Astyanax from drainages of southern Brazil (Characiformes: Characidae). Neotropical Ichthyology 11(3): 537-552. doi: 10.1590/S1679-62252013000300007

Lucena, C.A.S. and H.G. Soares. 2016. Review of species of the Astyanax bimaculatus "caudal peduncle spot" subgroup sensu Garutti \& Langeani (Characiformes, Characidae) from the rio La Plata and rio São Francisco drainages and coastal systems of southern Brazil and Uruguay. Zootaxa 4072(1): 101-125. doi: 10.11646/zootaxa.4072.1.5

Lucinda, P.H.F. 2008. Systematics and biogeography of the genus Phalloceros Eigenmann, 1907 (Cyprinodontiformes: Poeciliidae:
Poeciliinae), with the description of twenty-one new species. Neotropical Ichthyology 6(2): 113-158. doi: 10.1590/S167962252008000200001

Lütken, C.F. 1875. Characinae novae Brasiliae centralis a clarissimo J. Reinhardt in provincia Minas-Geraes circa oppidulum Lagoa Santa in lacu ejusdem nominis, flumine Rio das Velhas et rivulis affluentibus collectae, secundum characteres essentiales breviter descriptae. Oversigt over det Kongelige Danske Videnskabernes Selskabs Forhandlinger og dets Medlemmers Arbeider, Kjøbenhavn 1874(3): 127-143.

Majolo, M.A. 2005. Estudo da taxocenose de peixes na Ilha do Andrade, bacia hidrográfica do rio Taquari, Arroio do Meio, Rio Grande do Sul - Brasil [M.Sc. dissertation]. Porto Alegre: Universidade Federal do Rio Grande do Sul. 120 pp.

Malabarba, L.R. 1989. Histórico sistemático e lista comentada das espécies de peixes de água doce do sistema da Laguna dos Patos, Rio Grande do Sul, Brasil. Comunicações do Museu de Ciências e Tecnologia da PUCRS, Série Zoologia 2: 107-179.

Malabarba, L.R. and S.H. Weitzman. 2003. Description of a new genus with six new species from southern Brazil, Uruguay and Argentina, with a discussion of a putative characid clade (Teleostei: Characiformes: Characidae). Comunicações do Museu de Ciências e Tecnologia da PUCRS, Série Zoologia 16(1): 67-151.

Malabarba, L.R., C.B. Fialho, J.A. Anza J.A., J.F. Santos and G. N. Menezes. 2009. Peixes; pp. 131-156, in: I. Boldrini (ed.). Biodiversidade dos Campos do Planalto das Araucárias. Brasília: MMA.

Maltchik, L., D.A. Müller and C. Stenert. 2005. Fish assemblages dynamics in a shallow floodplain lake in the South of Brazil. Acta Limnologica Brasiliensia 17(2): 185-198.

Menezes, N.A. and A.C. Ribeiro. 2010. Oligossarcus jacuiensis (Characiformes: Characidae), a new species from the Uruguay and Jacuí River basins, southern Brazil. Neotropical Ichthyology 8(3): 649653. doi: http://dx.doi.org/10.1590/S1679-62252010000300010

Ottoni, F.P. and M.M. Cheffe. 2009. A new species of Australoheros from the upper rio das Antas, laguna dos Patos System, southern Brazil. Spixiana 32(1): 153-159.

Pelayo-Villamil, P., C. Guisande, P.R. Vari, A. Manjarés-Hernandéz, E. García-Rosello, J. González-Dacosta, J. Heine, L.G. Vilas, B. Patti, E.M. Quinci, L.F. Jiménez, C. Grnanado-Lorencio, P.A. Tedesco and J.M. Lobo. 2014. Global diversity patterns of freshwater fishes - potentional victims of their own success. Diversity and Distribution. doi: 10.1111/ddi.12271

Petry, A.C. and U.H. Schulz. 2006. Longitudinal changes and indicator species of the fish fauna in the subtropical Sinos River, Brazil. Journal of Fish Biology 69: 272-290. doi: 10.1111/j.10958649.2006.01110.x

Quoy, J.R.C. and J.P. Gaimard. 1824-1825. Description des Poissons; Chapitre IX, [1824]: 1-328, [1825]: 329-616, in: L. de Freycinet (ed.). Voyage autour du monde: entrepris par ordre du roi ... exécuté sur les corvettes de S. M. l'Uranie et la Physicienne, pendant les années 1817, 1818, 1819 et 1820 .... Paris: Pillet. http://biodiversitylibrary.org/page/40871183

Reis, R.E. and S.A. Schaefer. 1998. New cascudinhos from southern Brazil: systematics, endemism, and relationships (Siluriformes, Loricariidae, Hypoptopomatinae). American Museum Novitates 3254: 1-25. http://hdl.handle.net/2246/3154

Reis, R.E., S.O. Kullander and C.J. Ferraris Jr. 2003. Check list of the freshwater fishes of South and Central America. Porto Alegre: EDIPUCRS. 742 pp.

Regan, C.T. 1904. A monograph of the fishes of the family Loricariidae. Transactions of the Zoological Society of London 17(1): 191-350. http://biodiversitylibrary.org/item/48598

Ribeiro, M.F. and A. Köhler. 2007. Ictiofauna do rio Pardinhos, RS, Brasil. Cadernos de Pesquisa, Série Biologia 19(2): 37-45.

Ríncan, O. and Kullander, S.O. 2008. The Australoheros (Teleostei: 
Cichlidae) species of the Uruguay and Paraná River drainages. Zootaxa 1724: 1-51.

Rodriguez, M.S. and R.E. Reis, R.E. 2008. Taxonomic review of Rineloricaria (Loricariidae: Loricariinae) from the Laguna dos Patos drainage, southern Brazil, with the descriptions of two new species and the recognition of two species groups. Copeia 2008(2): 333-349. doi: 10.1643/CI-06-218

Saccol-Pereira, A. and C.B. Fialho. 2010. Seasonal and diel variation in the fish assemblage of a Neotropical delta in southern Brazil. Iheringia, Série Zoologia 100(2): 169-178. doi: 10.1590/S007347212010000200013

SEMA (Secretaria do Meio Ambiente). Base de dados. Accessed at http://www.sema.rs.gov.br/conteudo.asp?cod_menu=56\&cod_ conteudo=6250, 20 June 2012.

Silva, J.F.P. 1998. Revisão taxonômica das espécies de Bryconamericus (Eigenmann, 1907) do sul e sudeste do Brasil (Ostariophysi, Characidae) [M.Sc. dissertation]. Porto Alegre: Pontifícia Universidade Católica do Rio Grande do Sul. 107 pp.

Silva, G.N.M. 2009. Convergência ecomorfológica entre comunidades de peixes com histórias biogeográficas distintas [M.Sc. dissertation]. Porto Alegre: Universidade Federal do Rio Grande do Sul. 47 pp.

Súarez, Y.R. and M. Petrere-Júnior. 2005. Organização das assembléias de peixes em riachos da bacia do rio Iguatemi, Estado do Mato Grosso do Sul. Acta Scientiarium 27(2): 161-167. doi: 10.4025/actascibiolsci.v27i2.1350

Tagliani, P.R.A. 1994. Ecologia da assembléia de peixes de três riachos da planície costeira do Rio Grande do Sul. Atlântica 16: 55-68.

Thomaz, A.T., D. Arcila, D., G. Ortí and L.R. Malabarba. 2015. Molecular phylogeny of the subfamily Stevardiinae Gill, 1858 (Characiformes: Characidae) classification and the evolution of reproductive traits. BMC Evolutionary Biology 15: 146. doi: 10.1186/s12862-015-0403-4

Valenciennes, A. 1834-1842. Poissons; pp. 1-16, in: A. d'Orbigny (ed.). Voyage dans l'Amérique méridionale: (le Brésil, la république orientale de l'Uruguay, la République argentine, la
Patagonie, la république du Chili, la république de Bolivia, la républiquedu Pérou), exécuté pendant les années 1826, 1827, 1828, 1829, 1830, 1831, 1832, et 1833.

Vannote, R.L., G.W. Mishall, K.W. Cummins, J.R. Sedell and C.E. Cushing. 1980. The River Continuum Concept. Canadian Journal of Fisheries and Aquatic Sciences 37(1): 130-137. doi: 10.1139/ f80-017

Vidal, L.V.O., R.C.B. Albinati, A.C.L. Albinati, A.D. Lira, T.R. Almeida and G.B. Santos. 2008. Eugenol como anestésico para a tilápia do Nilo. Pesquisa Agropecuária Brasileira 43(8): 1069-1074.

Vilella, F.S., F.G. Becker, S.M. Hartz and G. Barbier. 2004. Relation between environmental variables and aquatic megafauna in a first order stream of the Atlantic Forest, southern Brazil. Hydrobiologia 528: 17-30. doi: 10.1007/s10750-004-0688-6

Volcan, M.V., A.C. Gonçalves and L.E.K. Lanés. 2011. Distribution, habitat and conservation status of two threatened annual fishes (Rivulidae) from southern Brazil. Endangered Species Research 13: 79-85. doi: $10.3354 /$ esr00316

Wiley, E.O. and G.D. Johnson. 2010. A teleost classification based on monophyletic groups; pp. 123-182, in: J.S. Nelson, H.P. Schultze and M.V.H. Wilson (eds.). Origin and Phylogenetic Interrelationships of Teleosts. Müchen: Verlag Dr. Friedrich Pfeil.

Winckler-Sosinski, L.T., A. Schwarzbold and U.H. Schulz. 2009. Fish assemblage structure in altitude rivers under the effect of exotic species introduction, northeast of Rio Grande do Sul, Brazil. Acta Limnologica Brasiliensia 21(4): 473-482.

Winemiller, K.O., A.A. Agostinho and P.E. Caramaschi. 2008. Fish ecology in tropical streams; pp. 336-346, in: D. Dudgeon (ed.). Tropical Stream Ecology. San Diego, California: Academic Press.

Author contributions: $\mathrm{KOB}$ collected data, verified the specimens and wrote the text. $\mathrm{CBF}$ wrote the text.

Received: 17 November 2015

Accepted: 17 March 2016

Academic editor: Tiago P. Carvalho 